\title{
From a Dictionary to the Copyright: Linguistic and Legal Aspects of Noah Webster's Media Discourse
}

\author{
Yury Luchinsky, Alexander Ostashevskyy and Regina Valerievna Patyukova* \\ Kuban State University, Krasnodar - 350040,Russia; patukovaregina@mail.ru
}

\begin{abstract}
The article examines the complex process of forming the national sociocultural model in the US in the last two decades of the eighteenth century in the context of the creative activity of one of the leaders of the federalist parties - Noah Webster (1758-1843). Webster's contribution to the development of national identity cannot be overestimated, since he was able to realize himself as an editor, essayist, lexicographer and reformer of the English language, as well as a lawmaker, one of the authors of the American concept of copyright. All these components of Webster's personality are analyzed in general linguocultural aspect and legal contexts typical of the America of the specified period, taking into account the influence of the existing at the time media practices on the minds of his contemporaries. Webster, being inside the system of informational influence (as a publicist and an editor), defined the 'agenda', pushing and sharpening issues that he considered important for the creation of a new nation. Two extremely complex tasks (a linguistic reform and protection of intellectual property), which had to be located in different areas of application, turned to be united in the media discourse proposed by Webster and were put into practice in the framework of the available historical, cultural and political situation.
\end{abstract}

Keywords: Copyright Act of 1790, Hermeneutic Microhistory, Media Discourse, Noah Webster, Sociocultural Model of the US, The English Language Spelling Reform

\section{Introduction}

The problem of studying the national identity formation as a component of the sociocultural model of a certain country remains relevant in various areas of modern science - from philosophy, history and culturology to philology and medialogy.

Analysis of the process of the American sociocultural model formation is interesting from the view point of the relatively short time perspective and in terms of a solid source base, allowing detailed study of a particular phenomenon of the period under review.

The concept of microhistory when a biography is used as a "sociocultural measurement of history" seems an advanced one (Giovanni Levi, Hans Medick, S.N. Ikonnikova and others) $)^{1-3}$.
Typology of historical biographies developed by Giovanni Levi includes four basic types - 'modal', 'contextual', 'deviant' and the fourth type of biographic genre which he called 'hermeneutic'.

In the latter "the spiritual world of the individual, the relationship to other people is brought to the forefront, the role of dialogue and communication between peoples and cultures is emphasized. Special attention is given to the freedom of choice, independence in decision-making, identification of individual strategies and practices, which are the internal causes of changes in the society. Whereas in previous versions of biographical descriptions, the personality just reflected social conditions passively enough, it was a kind of mirror, but now the roles are reversed"3.

\footnotetext{
${ }^{*}$ Author for correspondence
} 
The approach proposed in this research can be defined as 'media-hermeneutic microhistory' when "detailed examination"' is media extrapolated to 'large matrices' of the historical and cultural space. From the viewpoint of communicative narrative the concept of Professor David Boje $^{4}$ is close to our approach in terms of methodology.

\section{The Problem of Forming a New Cultural Space in the US}

American intellectual life of the late eighteenth century was characterized by a total lack of confidence in own abilities and a kind of existential fear of Europe, as compared to the European literary tradition, writing experiments by local authors looked archaic and often helpless.

On the one hand, the United States could be proud of its achievements in the field of state-building and legislation, certain technical progress and professed to cultural parity, but in addition to the intentions, the evidence of the full-fledged cultural tradition was also required that America might present to Europe.

Fisher Ames ${ }^{5}$, another representative of the Federalist Party, congressman, speaker, publicist, who was elected the president of Harvard University in 1805, pondered this problem at the turn of the century.

He wrote in the essay American Literature (1800):

"Few speculative subjects have exercised the passion more or the judgment less, than the inquiry, what rank our country is to maintain in the world for genius or literary attainments. Whether in point of intellect we are equal to Europeans or only a race of degenerative creoles; whether our artists and authors have already performed much and promise every thing, whether the muses, like the nightingales, are too delicate to cross the salt water or sicken and mope without song, if they do, are themes upon which we Americans are privileged to be eloquent and loud".

Professor Edward Cahill ${ }^{6}$ drew attention to the same aspect in the chapter "Democracy and American Literature"' in the book devoted to the mutual influence of aesthetics, literature and politics in the early American culture.

Analyzing the situation existing in American literature at the turn of the centuries, Ames came to a disappointing for the American national pride conclusion that the poem by Joel Barlow (1754-1812) can hardly be compared to the epic of Homer and Hesiod.

Barlow's poem, the original text of which was published in The Connecticut Magazine, was intended to establish new forms of national literature. It was full of rhetoric and edification. In the preface to the first edition it was said that "the real object of the poem concerns the attempt to instill love for the national freedom and remove the harmful passion for violence and war, to show that any healthy morality, a good form of government and hope for a permanent peace must be based on the republican principles represented by the new American nation"?.

In Barlow's poem The Columbiad (1807) angel Hesper, being the 'Spirit of the West', which is practically equal to the Spirit of America (Guardian Genius), led exhausted Columbus out of his imprisonment to 'the hill of vision', where he discloses the future of the world to the great seafarer. The first four books of poems narrate about the history of the world until 1763, the next three books focus on the history of America during the War for Independence and the final three parts describe the unity of all nations in peace and prosperity:

Here then, said Hesper, with a blissful smile,

Behold the fruits of thy long years of toil.

To yon bright borders of Atlantic day,

Thy swelling pinions of Atlantic day.

And taught mankind such useful deeds to dare,

To trace new seas and happy nations rear;

Till by fraternal hands their sails unfurl'd,

Have waved at last in union o'er the world ${ }^{8}$.

The publication of the poem, placed in a luxurious binding, was one of the most expensive in American book printing history, but soon enthusiasm faded and The Columbiad by Joel Barlow is now known as "one of the most complete failures in American poetic history".

Another essential aspect related to the specifics of the prevalence of various literary genres in becoming civilization may be noted in striving to create epic works, which was typical of the American culture of this period.

"Drama... develops in the home country, Epic among migrating people, whether they migrate to France or England or Germany - or to Ionia, for the analogy with Greek Drama holds good here too" ${ }^{10}$. 


\section{Linguistic and Legal Aspects of Noah Webster's Media Discourse}

The most flaming radicals demanded full independence of America from Britain in the field of culture. Noah Webster (1758-1843) was a supporter of a similar development concept suggesting the project "cultural and linguistic separatism".

Webster was a lawyer by profession, but nationwide fame came to him after the period from 1783 to 1785 when he had published his three-volume work: A Grammatical Institute of the English Language, also known as BlueBacked Speller and perceived by his contemporaries as a "challenge to traditionalism and complacency" Blue-Backed Speller was followed by the publication of The American Spelling Book (1806) and An American Dictionary of the English Language (1806, 1828), which now bears his name.

At the same time Webster was at the top pf the ladder in the journalistic world of Hartford, Connecticut and then of New York, which allowed him to communicate his ideas to a wider audience. He understood the importance of the newspaper text in influencing public opinion, as at the time the newspaper acted as the main communication channel.

In this aspect Webster's editorial experience is of interest, in New York Webster edited a literary magazine The American Magazine (1787-1788) and a daily newspaper The American Minerva (1793-1803), which became a platform for the promotion of cultural independence ideas.

The American Minerva, the first daily newspaper in New York, was published on December 9, 1793 with Webster's program article, in which he outlined his vision of the newspaper business in the United States, having in his opinion a great advantage in the information impact on public consciousness because of its relative cheapness, speed of delivery and circulation and set out the challenges facing the American nation, among which the main place was taken by dissemination of knowledge (one of the leading concepts of the enlightenment).

"It is the singular felicity of the Americans and a circumstance that distinguishes this country from all others, that the means of information are accessible to all descriptions of people. Most of the citizens of America are not only acquainted with letters and able to read their native language; but they have a strong inclination to acquire and property to purchase, the means of knowledge. Of all the means of knowledge, newspapers are the most eagerly sought after and the most generally diffused. In no country on earth, not even Great Britain, are newspapers so generally circulated among the body of the people, as in America. To this facility of spreading knowledge over our country, may, in a great degree, be attributed, that civility of manners, that love for peace and good order and that property of public conduct, which characterize the substantial body of citizens in the United States. $<\ldots>$ But newspapers are not only the vehicles of what is called news; they are the common instruments of social intercourse, by which the citizens of this vast republic constantly discourse and debate with each other on subjects or public concern"12.

At the same time newspapers were considered by Webster as an ideal tool for shaping the idea of a republican form of government.

In 1789 Webster published An Essay on the Necessity, Advantages and Practicability of Reforming the Mode of Spelling, which sounded as a linguistic Declaration of Independence ${ }^{11}$.

Suggestions introduced by Webster included:

1. Refusal of "all superfluous or silent letters"; therefore it was required to write 'bred' instead of 'bread', ' $g i v$ ' instead of 'give', 'bilt' instead of 'built', 'relm' instead of 'realm', 'frend' instead of 'friend';

2. Unification of diphthong spellings, designated by vowels 'ee', 'ea', 'ie'; from now onward 'ee' should be written everywhere, that is 'meen' instead of 'mean', 'neer' instead of 'near,' 'speek' instead of 'speak', 'greev' instead of 'grieve', 'beleev' instead of 'believe;

3. Replacement of the Greek derivative 'ch' denoting sound $[\mathrm{k}]$ with a consonant ' $\mathrm{k}$ '; therefore it was necessary to write 'karakter' instead of 'charakter', 'korus' instead of 'chorus', 'arkitecture' instead of 'architecture';

4. Replacement of the French derivative 'ch' with a combination of consonants 'sh', as complying with the standard English pronunciation; therefore it was required to write 'masheen' instead of 'machine', 'shevaleer' instead of 'chevalier'; etc.

5. The final fixation of the differences between the British and American versions of English was considered by Webster as the main advantage of the proposed 
spelling reform. In Noah Webster's opinion, it was absolutely necessary, as "a national language is a bond of national union. Every engine should be employed to render the people of this country national; to call their attachments home to their own country; inspire them with the pride of national character. However they may boast of Independence and the freedom of their government, yet their opinions are not sufficiently independent; an astonishing respect for the arts and literature of their parent country and a blind imitation of its manners, are still prevalent among the Americans"13.

Language reform was perceived by Webster as a component part of national cultural policy and he insisted on the soonest implementation of this reform.

Over time, the bellicose Americanism of Noah Webster sounds quite curious, but apparently it was a necessary stage in the process of cultural self-identity of the nation. Attempts to express the meaning and the spirit of the aborning in plain view civilization in the word captured most men of letters who were looking for 'foothold' to create a national cultural tradition.

Almost simultaneously with the work on the language reform Noah Webster began working on promoting the idea of Copyright Act. The problem was that the British Law on the Protection of Intellectual Property Rights, socalled the Statute of Anne, protecting the rights of British authors to profit from the sale of their works for fourteen years with the possibility of a single extension for another fourteen years, was not applied to the American colonies.

Until 1783 only three local copyright acts were passed with minimum terms of copyright protection. That is why in 1782 Webster made the first attempt to convince the members of the Continental Congress in Philadelphia to adopt a law that provided copyright protection. However, according to the Articles of Confederation (the first version of the US Constitution), the Continental Congress had no right to enact the Federal Copyright Act, but could only recommend it to certain states.

The first steps in this direction failed and only in Connecticut, Webster managed to be entitled for the printing and distribution of his works for thirteen years. Thus, a precedent was set, and soon, the General Assembly of Connecticut adopted the first law in the United States granting authors the exclusive right to profit from the publication of their works for fourteen years. This law was named An Act for the Encouragement for Literature and Genius.
Webster continued promotion of the law on copyright protection and by 1786 all thirteen states had enacted similar laws (Pennsylvania was the last of them), but nevertheless it was required to adopt such a law at the federal level.

And only in 1790 the US Congress adopted the Copyright Act, providing copyright protection throughout the country. It was called An Act for the Encouragement of Learning, by Securing the Copies of Maps, Charts and Books, to the Authors and Proprietors of Such Copies, during the Times therein Mentioned and on May 31, 1790 it was signed by US President George Washington and US Secretary of State Thomas Jefferson. The text of the law was published for the general public in a Boston newspaper The Columbian Centinel.

Copyright Act of 1790 replicated the Statute of Anne in many ways, except for the 'mirror response' - it protected only the rights of American authors. This resulted in flourishing of publishing piracy, as English literary products were in high demand, while local ones were almost unsaleable. It became clear that "Noah Webster was overzealous in his patriotism: Copyright Act of 1790 protected only the works by American authors, while in Britain the copyright protection could be achieved under the general law or gentlemen's agreement on the basis of the first publication and regardless of the author's nationality"1.

\section{Conclusion}

At the end of the $18^{\text {th }}$ century, the concept of Americanism could be reduced to a fairly simple formula: "Commitment to the republican ideals, the denial of monarchism, a strive for democratic freedoms and peaceful building of the national home". Sometimes this formula is called the "federalist" one as the concept of "Americanism" was opposed to cosmopolitanism, identified with the Jacobinism of the French Revolution. The opposition of "Americanism/cosmopolitanism" hid the trend that influenced the formation of the national literature and was objectively manifested in the most revolutionary eras.

This refers to the 'neo-archaic' tastes firmly established in American literature at the turn of the century. Romanticism as a new trend in the European culture was associated with the revolution in France and therefore it was perceived in a negative aspect. And American revolutionary gains were to be reflected in the stylistics 
of the ancient culture or in the best samples of British tradition, mainly of the beginning of the $18^{\text {th }}$ century.

A "cultural foundation" was built according to the canons of "neo-classicism", which explains the predominance of pseudo-epic works bearing the stamp of Boileau's "Poetics", pamphlets, didactic essays, etc.

All the complexity of the situation was that the effect of retardation (or non-synchronization of cultural development) was preserved in the field of culture. No experiments in the field of culture were practically observed. New ideas were dressed in traditional, established forms and therefore most works of Americans were unconsciously perceived as old-fashioned or epigonic. It was an exercise in futility to astonish the Europeans with creation of "obsolete" literary samples and the local literary triumphs (like Barlow's Columbiad) remained triumphs only on one side of the Atlantic.

The problem of attaining cultural autonomy was associated with certain ambivalence in the position of the Americans in the field of culture. Despite declarations of Noah Webster painted in the nationalistic tones, common language and cultural traditions firmly connected the United States and Britain. Inability to break these ties was too obvious. This was understood even by the most radical proponents of Americanism. Noah Webster, who was called by the contemporaries a "George Washington's cultural attaché" 14 , wrote that no national pride would cause him to put aside the volume of his favorite Addison and abandon his ${ }^{8}$. Therefore, the Bible, Shakespeare, Milton, Addison, Pope and others should remain as a common cultural source. It was necessary to renounce what Webster called "servile imitation".

Therefore, the language reform proposed by Noah Webster and not entirely successful (in the longer term) attempt to protect intellectual property rights, relating to the different spheres at first glance, were combined by
Webster in the single media discourse and contributed to the development of a new culture and national sociocultural model.

\section{References}

1. Levi G. On microhistory. In Peter Burke (Editor) new perspectives on historical writing. Cambridge: Polity Press; 1991. p. 93-113.

2. Medick, H. Micro history [PhD Thesis]. 1994; 4:193-202. [in Russian]

3. Ikonnikova SN. Biography as a sociocultural measurement of history. Journal of Cultural Research. 2011; 4(6). Retrieved from http://www.cr-journal.ru/rus/journals [in Russian].

4. Boje DM. Narrative methods for organizational and communication research. London: Sage Publishing; 2001.

5. Works of Fisher Ames compiled by a number of his friends. Boston: T.B. Wait and Co; 1809.

6. Cahill E. Liberty of the imagination: Aesthetic theory, literary form and politics in the early United States. Philadelphia: University of Pennsylvania Press; 2012.

7. Parrington VL. Main currents in American thought: An interpretation of American Literature from the beginning to 1920, in 3 volumes. Moscow: Izdatelstvo Inostrannaya Literatura; 1962; 1. [in Russian].

8. Foerster N, Grabo N, Nye RB, Carliste F, Falk R. (Editors) American Poetry and Prose: In 3 volumes. New York: Houghton Mifflin College; 1970; 1.

9. Nye RB. The cultural life of the new nation: 1776-1830. New York: Harper and Row; 1960.

10. Toynbee AJ. A study of history. Moscow: Progress; 1991. [in Russian].

11. Spiller RF, Thorp W, Johnson TH, Canby HS. (Editors) Literary history of the United States: In 3 volumes. Moscow: Progress; 1977; 1. [in Russian].

12. The American Minerva. 1793 Dec.

13. Thorp W, Curti M, Baker C. (Editors.) American Issues. Philadelphia: Lippincott; The Social Record. Chicago; 1955; 1.

14. Kendall J. The forgotten founding father: Noah Webster's Obsession and the Creation of an American Culture. London: Penguin Books; 2010. 